\title{
LAJU TANGKAP DAN ANALISIS USAHA PENANGKAPAN IKAN KARANG DENGAN PANCING RAWAI DI PERAIRAN BATUKARAS, JAWA BARAT
}

\author{
Wiwiet An Pralampita*) dan Iriandi Eka Putra*
}

\begin{abstract}
ABSTRAK
Penelitian tentang laju tangkap dan analisis usaha ikan karang di perairan Batukaras. Ciamis, Jawa Barat telah dilakukan pada tahun 1992. Data yang dikumpulkan dianalisis secara deskriptif dengan tabulasi silang dan metode Rapid Rural Appraisal. Hasil penelitian menyimpulkan bahwa ikan karang yang tertangkap di perairan Batukaras didominasi oleh kakap merah (Lutjanidae) dan kerapu (Serranidae). Laju tangkap (CPUE) ikan karang cenderung naik pada musim Barat maupun musim Timur dan sebaliknya cenderung turun pada musim peralihan. Nilai $R / C$ ratio adalah sebesar 2,5 yang berarti bahwa usaha penangkapan ikan karang di perairan Batukaras adalah efisien atau menguntungkan.
\end{abstract}

\begin{abstract}
Catch rates and exploitation analysis of coral reef fishes in Batukaras, West Java. By: Wiwiet An Pralampita and Iriandi Eka Putra.

Investigation on the catch rate and exploitation analysis of coral reef fishes in Batukaras was undertaken in 1992. The data collected were analysed descriptively by cross tabulation and Rapid Rural Appraisal. The research concluded that coral reef fishes caught in the Batukaras water was dominated by red snapper (Lutjanidae) and grouper (Serranidae). The CPUE of coral reef fishes tend to increase in West and East seasons, but decrease in transition season. The $R / C$ ratio value was 2.5 showing that fishing effort of coral reef fishes in the Batukaras water was efficient.
\end{abstract}

KEYWORDS: snapper, grouper, coral reef fish, drift longline.

\section{PENDAHULUAN}

Perairan karang merupakan suatu ekosistem yang paling subur dibandingkan dengan perairan lainnya. Perairan ini mempunyai produktivitas tinggi dengan sumber hayati yang sangat beranekaragam dan hubungan di antaranya sangat erat. Perairan karang Indonesia merupakan perairan karang yang terluas di kawasan Asia Tenggara yaitu sekitar $6.800 \mathrm{~km}^{2}$ (Dwiponggo, 1989).

Potensi lestari sumber daya ikan karang di perairan selatan Jawa yang luasnya $380 \mathrm{~km}^{2}$ yaitu 1.108 ton/tahun. Jumlah tersebut hanya $2 \%$ saja dari potensi lestari sumber daya ikan karang di perairan Indonesia yaitu 52.224 ton/tahun (Hutomo et al., 1991).

Sumber bahan makanan utama yang dihasilkan dari terumbu karang adalah ikan. Pada tahun 1979, ekspor Indonesia dari jenis-jenis ikan yang mempunyai hubungan erat dengan terumbu karang, mencapai lebih dari US\$ 79 juta atau 16\% dari seluruh hasil ekspor ikan.

Ikan-ikan yang seluruh hidupnya berada di sekitar karang misalnya ikan kerapu (grouper), ikan cod dan ikan lencam dapat ditangkap sepanjang tahun, tetapi hasil tangkapan dalam jumlah besar jarang didapatkan (Mulyanto, 1986). Pengelolaan sumber daya ikan karang sangat kompleks karena penangkapannya berdasarkan adanya interaksi antar spesies, seringkali harus menggunakan alat tangkap yang berbeda-beda. Walaupun suatu perairan di Indonesia diduga tingkat pengusahaannya sudah tinggi, tetapi informasi tentang analisis usaha khususnya tentang ikan karang masih kurang.

Nikijuluw et al. (1988) mensinyalir bahwa manajemen pintu terbuka dalam pengusahaan sumber daya perairan karang telah menyebabkan penurunan produksi dan kualitas sumber dayanya yang mengakibatkan semakin mengecilnya jumlah penerimaan para pengusaha di wilayah tersebut. Untuk mengetahui laju tangkap dan besarnya penerimaan para nelayan penangkap ikan karang, telah dilakukan suatu penelitian tentang analisis usaha ikan karang ekonomis penting di daerah perairan Batukaras, Kabupaten Ciamis, Jawa Barat.

\section{BAHAN DAN METODE}

Penelitian ini dilakukan pada tahun 1992 di perairan Batukaras, Kabupaten Ciamis, Jawa

Peneliti pada Balai Penelitian Perikanan Laut 
Barat. Sampel ikan dalam penelitian ini diperoleh dari hasil tangkapan komersial usaha perikanan rakyat di daerah ini. Pengambilan sampel ikan karang terutama pada jenis ikan kakap merah (Iutjanidae) dan kerapu (Serranidae). Selanjutnya terhadap individu ikan sampel dilakukan pengamatan jenis menggunakan buku pedoman Thomas et al. (1981) dan Kohno et al. (1990), serta diukur panjang total dan ditimbang bobotnya. Selain data hasil tangkapan perikanan rakyat diperoleh juga data sekunder dari TPI, KUD setempat, yaitu dengan merekapitulasi data harian menjadi data bulanan dan tahunan.

Sebagai indikasi kelimpahan stok dapat digunakan perkembangan laju tangkap (Catch Per Unit Effort, CPUE) (Gulland, 1983). Pada awal pemanfaatan stock, nilai CPUE meningkat dengan bertambahnya upaya (effort), tetapi bila pertambahan tersebut terjadi terus-menerus dan tanpa terkendali, nilai CPUE akan menurun.

Untuk analisis ekonomi dihitung dengan menggunakan analisis deskriptif dengan pendekatan biaya dan penerimaan $(\mathrm{R} / \mathrm{C})$, mengikuti Riyanto (1982). Untuk menghitung penyusutan menggunakan metode garis lurus yaitu dengan membagi harga pembelian dengan umur ekonomis alat yang bersangkutan.

\section{HASIL DAN BAHASAN}

\section{Daerah Penangkapan}

Batukaras merupakan salah satu daerah penghasil ikan di Kabupaten Ciamis, Jawa Barat.
Perikanan di daerah ini mempunyai ciri utama, yaitu banyaknya jenis alat tangkap yang dioperasikan pada daerah penangkapan yang sama, sehingga persaingan cukup ketat antar jenis alat tangkap akan menonjol terutama pada jenis-jenis alat yang mempunyai target penangkapan yang sama.

Daerah penangkapan ikan karang yang dimanfaatkan nelayan adalah perairan Batukaras yang terletak di dalam Teluk Parigi sampai Legok Jawa (Gambar 1). Hal ini menunjukkan bahwa nelayan Batukaras sama dengan nelayan Pangandaran (Basuki et al., 1989) yaitu belum memanfaatkan perairan lepas pantai untuk daerah tangkapannya. Kecenderungan nelayan menangkap di daerah teluk dikarenakan perairan teluk mempunyai potensi cukup besar yang dapat diusahakan oleh nelayan skala kecil dan merupakan daerah terlindung dari ganasnya gelombang pantai Selatan.

\section{Alat dan Musim Penangkapan}

Alat tangkap yang dioperasikan di perairan Batukaras sebanyak lima jenis alat tangkap yaitu jaring arat, jaring udang, jaring sirang, pancing prawe (nama lokal untuk pancing rawai) dan gillnet nylon.

Alat tangkap yang dominan digunakan oleh nelayan untuk menangkap ikan karang di daerah ini ialah pancing rawai. Hal ini sesuai dengan Subani \& Barus (1988), bahwa usaha penangkapan ikan kakap merah, lencam dan kerapu biasanya lebih efektif menggunakan pancing rawai



Gambar 1. Peta lokasi Perairan Batukaras.

Figure 1. Map showing the location of Batukaras Waters. 
sebab habitat dari ikan-ikan tersebut umumnya di daerah yang berkarang dan berbatu, jarang berada di tempat yang datar dan berlumpur atau berpasir. Hasil tangkapan seluruh jenis ikan dengan menggunakan pancing rawai rata-rata $41 \%$ setiap bulannya dari hasil tangkapan seluruhnya dibandingkan dengan alat tangkap lainnya yang hanya sekitar 3\%-23\%.

Pancing rawai ini dioperasikan malam atau siang hari, dengan umpan udang, teri atau layur. Sedangkan jumlah mata pancing yang umum digunakan di sini adalah 200-250 mata pancing. Alat tersebut dioperasikan dengan menggunakan perahu kayu maupun fiber yang mempunyai ukuran sekitar panjang 8,4 m, lebar 0,9 m serta tinggi $0,6 \mathrm{~m}$ dan dilengkapi dengan mesin $7 \mathrm{HP}$ atau $15 \mathrm{HP}$ dan 2 orang ABK. Alat tersebut dioperasikan pada kedalaman 20-25 m.
Di daerah lain pancing rawai pada umumnya dapat dioperasikan sepanjang tahun. Begitu pula di perairan Batukaras, alat tersebut juga dapat dioperasikan sepanjang tahun karena daerah tangkapannya terletak di dalam Teluk Parigi. Satu trip dari pancing rawai ini adalah satu hari dan biasanya dalam satu bulan maksimum 26 trip (Tabel 1).

\section{Hasil Tangkapan}

Hasil tangkapan pancing rawai di perairan karang Batukaras didominasi oleh ikan lainnya, sedangkan jenis ikan karang hanya kakap merah dan kerapu (Tabel 2). Hasil tangkapan ikan lainnya ialah tongkol, layur, tenggiri, dan lainlain, di mana ikan tongkol adalah 1,3-28\%.

Tabel 1. Hari operasi pancing rawai bulan Januari sampai Desember 1992 di Perairan Batukaras, Ciamis, Jawa Barat.

Table 1. Operation days of drift long line from January to December 1992 in Batukaras Waters, Ciamis, West Java.

\begin{tabular}{cc}
\hline $\begin{array}{c}\text { Bulan } \\
\text { Month }\end{array}$ & $\begin{array}{c}\text { Hari operasi } \\
\text { Days of operation }\end{array}$ \\
\hline 1 & 23 \\
2 & 20 \\
3 & 14 \\
4 & 12 \\
5 & 16 \\
6 & 26 \\
7 & 11 \\
8 & 13 \\
9 & 19 \\
10 & 17 \\
11 & 23 \\
12 & 24 \\
Rata-rata (Average) & 18 \\
\hline
\end{tabular}

Tabel 2. Rata-rata komposisi tangkapan pancing rawai di Perairan Batukaras pada tahun 1992.

Table 2. Average catch composition of drift long line in Batukaras Waters in 1992.

\begin{tabular}{cr}
\hline Ikan & \multicolumn{1}{c}{ Fish } \\
\hline Kakap merah (Red snapper) & Percentage \\
Kerapu (Grouper) & 19.84 \\
Lainnya (Others) & 11.25 \\
\hline Total & 68.91 \\
\hline
\end{tabular}


Perbandingan hasil tangkapan untuk ikan kakap merah berkisar antara 11,97-34,73\%, sedangkan untuk ikan kerapu berkisar antara 1,16-20,24\% (Tabel 3).

Ukuran kakap merah yang tertangkap selama penelitian ialah panjang total antara $40-75 \mathrm{~cm}$ dan bobot antara 1,9-3,8 kg. Ukuran kakap merah yang tertangkap sesuai dengan ukuran permintaan pasar yaitu $\geq 1,5 \mathrm{~kg}$ dan panjang $\geq 45,0 \mathrm{~cm}$ (Yunus et al., 1991). Sedangkan untuk kerapu yang tertangkap dari perairan ini merupakan ukuran ekonomis dengan panjang total $19.76 \mathrm{~cm}$ (Ahmad et al., 1991).

\section{Laju Tangkap (CPUE)}

Dari Gambar 2 dapat diketahui bahwa pada musim Barat yaitu bulan November sampai dengan Februari maupun musim Timur yaitu bulan April sampai dengan Juni, CPUE kakap merah, kerapu maupun ikan lainnya cenderung

Tabel 3. Persentase kakap merah dan kerapu dibanding total tangkapan menggunakan pancing rawai di Perairan Batukaras tahun 1992.

Table 3. Percentages of red snapper and grouper catch against total catch by drift longline in Batukaras Waters in 1992.

\begin{tabular}{crrrr}
\hline \multirow{2}{*}{$\begin{array}{c}\text { Bulan } \\
\text { Month }\end{array}$} & \multicolumn{2}{c}{$\begin{array}{c}\text { Kakap merah } \\
\text { Red snapper }\end{array}$} & \multicolumn{2}{c}{$\begin{array}{c}\text { Kerapu } \\
\text { Grouper }\end{array}$} \\
\cline { 2 - 5 } & \multicolumn{1}{c}{$(\mathrm{kg})$} & $\%$ & $\mathbf{( k g )}$ & \multicolumn{1}{c}{$\%$} \\
\hline 1 & 369.9 & 14.52 & 303.9 & 11.93 \\
2 & 1289.4 & 34.73 & 599.0 & 16.13 \\
3 & 121.8 & 18.48 & 94.7 & 14.36 \\
4 & 151.7 & 18.07 & 59.6 & 7.10 \\
5 & 521.5 & 17.67 & 278.3 & 9.43 \\
6 & 1125.4 & 25.17 & 905.1 & 20.24 \\
7 & 88.3 & 18.31 & 5.6 & 1.16 \\
8 & 176.3 & 21.28 & 72.2 & 8.72 \\
9 & 84.2 & 11.97 & 92.6 & 13.21 \\
10 & 90.2 & 13.65 & 36.8 & 5.60 \\
11 & 1901.5 & 21.17 & 1269.0 & 14.13 \\
12 & 1626.1 & 23.00 & 879.9 & 13.00 \\
\hline
\end{tabular}

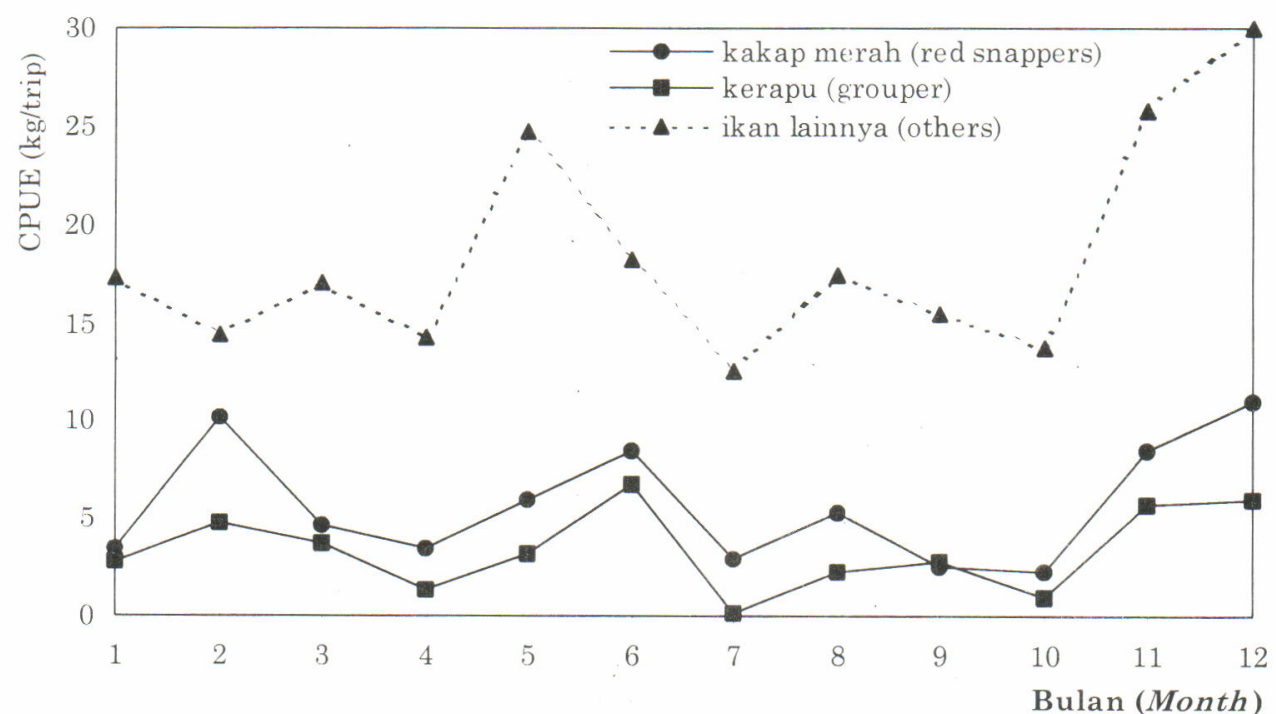

Gambar 2. Kecenderungan CPUE tertangkapnya ikan karang oleh pancing rawai di Perairan Batukaras dari Januari sampai Desember 1992.

Fugure 2. Trends of CPUE of coral reef fish caught by drift longline in Batukaras waters from January to December 1992. 
naik. Sedangkan pada waktu musim peralihan yaitu bulan Februari sampai dengan April dan bulan Juli sampai dengan Oktober, CPUE kakap merah, kerapu maupun ikan lainnya cenderung turun. Diduga kejadian ini disebabkan karena tiupan angin tidak tetap yang terjadi pada musim peralihan.

CPUE kakap merah tertinggi terjadi pada bulan Desember yaitu 10,99 kg/trip dan CPUE kerapu pada bulan Juni yaitu $6,76 \mathrm{~kg} /$ trip. Sedangkan CPUE kakap merah terendah terjadi pada bulan Oktober yaitu 2,31 kg/trip dan kerapu pada bulan Juli yaitu $0,18 \mathrm{~kg} /$ trip.

\section{Analisis Biaya}

Salah satu tujuan usaha penangkapan di suatu daerah untuk mengetahui pengoperasian alat tangkap tersebut (dalam hal ini pancing rawai) menguntungkan atau merugikan dan untuk mengetahui apakah unit alat tangkap tersebut dapat dipertahankan, dikembangkan atau dihentikan pengoperasiannya.

Dalam analisis usaha ini alat tangkap pancing rawai yang dianalisis dengan pertimbangan alat tangkap ini merupakan alat tangkap yang dominan jumlah hasil tangkapan kakap merah dan kerapunya. Dalam perhitungan ini jumlah operasi pancing rawai rata-rata 18 trip per bulan ( satu trip = satu hari).

Rata-rata modal investasi dalam satu unit usaha penangkapan pancing rawai sebesar $R p$ 2.759.000,- . Modal investasi yang ditanam adalah untuk pembelian perahu, mesin, alat tangkap, jangkar, tali tambang dan pelampung. Unit alat tangkap tersebut mempunyai umur ekonomis yang berbeda. Perahu mempunyai umur ekonomis paling lama enam tahun, mesin empat tahun, pancing satu tahun, jangkar lima tahun, tali tambang 0,5 tahun dan pelampung 0,5 tahun.

Pada dasarnya biaya tetap harus dikeluarkan secara periodik dengan tidak melihat apakah unit usaha tersebut beroperasi atau tidak. Pada unit alat penangkapan pancing rawai, biaya tetap hanya meliputi biaya depresiasi saja. Besarnya biaya depresiasi ialah Rp 596.800,- (Tabel 4), sedangkan biaya lainnya seperti surat izin usaha dan surat-surat lain diabaikan karena tidak semua unit penangkapan pancing rawai memiliki SIUP.

Biaya tidak tetap adalah biaya yang dikeluarkan untuk setiap kali operasi penangkapan. Biaya tidak tetap yang dikeluarkan untuk operasi penangkapan meliputi biaya pembelian bahan bakar minyak (solar), umpan, es dan perbekalan. Besarnya biaya operasi penangkapan dalam satu unit penangkapan pancing rawai sebesar $R p$ 27.000,per trip atau Rp 5.832.000,- per tahun di mana jumlah operasi penangkapan dalam satu tahun 216 trip.

Struktur biaya yang dikeluarkan untuk pengoperasian alat tangkap adalah untuk pembelian solar Rp12.000,- (44,4\%), umpan Rp 10.000,$(37,1 \%)$, es $\operatorname{Rp~} 2.000,-(7,4 \%)$ dan perbekalan Rp 3.000,- (11,1\%) dari total biaya per trip (Tabel 5).

Biaya perawatan alat (perahu dan mesin) juga termasuk biaya tidak tetap. Besarnya biaya perawatan alat $R p$ 210.000,- per tahun. Biaya ini terdiri atas biaya pengecetan perahu Rp 90.000,per tahun, di mana pengecetan dilakukan tiap empat bulan sekali dan biaya untuk perbaikan mesin Rp 120.000,- per tahun. Jumlah biaya tidak

Tabel 4. Rata-rata investasi dari satu unit pancing rawai per unit usaha di Batukaras, 1992.

Table 4. Average investment in one unit of drift longline per effort unit in Batukaras, 1992.

\begin{tabular}{|c|c|c|c|}
\hline $\begin{array}{l}\text { Peralatan } \\
\text { Equipment }\end{array}$ & $\begin{array}{c}\text { Umur ekonomis } \\
\text { (tahun) } \\
\text { Economic shelf life } \\
\text { (year) }\end{array}$ & $\begin{array}{l}\text { Harga awal } \\
\text { Initial price }\end{array}$ & $\begin{array}{c}\text { Depresiasi } \\
\text { Depreciation } \\
(\mathrm{Rp})\end{array}$ \\
\hline Kapal (Boat) & 6 & $1,700,000$ & 283,300 \\
\hline Mesin (Motor) & 4 & 950,000 & 237,500 \\
\hline Pancing (Hook) & 1 & 25,000 & 25,000 \\
\hline Jangkar (Anchor) & 5 & 30,000 & 6,000 \\
\hline Tali (Rope) & 0.5 & 50,000 & 25,000 \\
\hline Pelampung (Buoy) & 0.5 & 4,000 & 20,000 \\
\hline \multicolumn{2}{|c|}{ Total } & $2,759,000$ & 596,800 \\
\hline
\end{tabular}


Tabel 5. Rata-rata biaya operasi per trip pancing rawai di Batukaras, 1992.

Table 5. Average operating cost per trip of drift longline in Batukaras, 1992.

\begin{tabular}{lccc}
\hline \multicolumn{1}{c}{$\begin{array}{c}\text { Masukan } \\
\text { Input }\end{array}$} & $\begin{array}{c}\text { Biaya per trip } \\
\text { Cost per trip } \\
\text { (Rp) }\end{array}$ & $\begin{array}{c}\text { Biaya per tahun } \\
\text { Cost per year } \\
\text { (Rp) }\end{array}$ & $\begin{array}{c}\% \\
\text { Percentage }\end{array}$ \\
\hline Bahan bakar (Fuel) & 12,000 & $2,592,000$ & 44.40 \\
Umpan (Bait) & 10,000 & $2,160,000$ & 37.10 \\
Es batu (Ice) & 2,000 & 432,000 & 7.40 \\
Suplai (Supplies) & 3,000 & 648,000 & 11.10 \\
\hline Total & 27,000 & $5,832,000$ & 100.00 \\
\hline
\end{tabular}

tetap seluruhnya (biaya operasi dan biaya perawatan alat) yang dikeluarkan pemilik alat tangkap dalam satu tahun adalah Rp 6.042.000,-

\section{Sistem Bagi Hasil}

Salah satu cara untuk memperbaiki kondisi sosial ekonomi nelayan perlu ditunjang dari sistem bagi hasil yang memadai. Sistem bagi hasil yang berlaku di Batukaras umumnya adalah $80 \%$ untuk pemilik dan $20 \%$ untuk pendega (ABK) dari hasil bersih setelah dipotong biaya retribusi dan biaya operasi (Gambar 3).

Dalam Undang-Undang No. 16/1964 pasal 3(1) tentang sistem bagi hasil dikatakan bahwa jika suatu usaha perikanan diselenggarakan atas perjanjian bagi hasil maka dari usaha itu kepada pihak nelayan penggarap harus diberikan paling sedikit:

a. Jika digunakan perahu layar yang diterima $75 \%$ dari hasil bersih.

b. Jika digunakan kapal motor paling sedikit $40 \%$ dari hasil bersih.

Undang-Undang No. 16/1964 pasal 3(1) bertujuan untuk mewujudkan masyarakat sosialis Indonesia pada umumnya, khususnya untuk meningkatkan taraf hidup para nelayan penggarap dan penggarap tambak serta memperbesar produksi ikan (Anonim, 1964). Membandingkan isi undang-undang tentang sistem bagi hasil

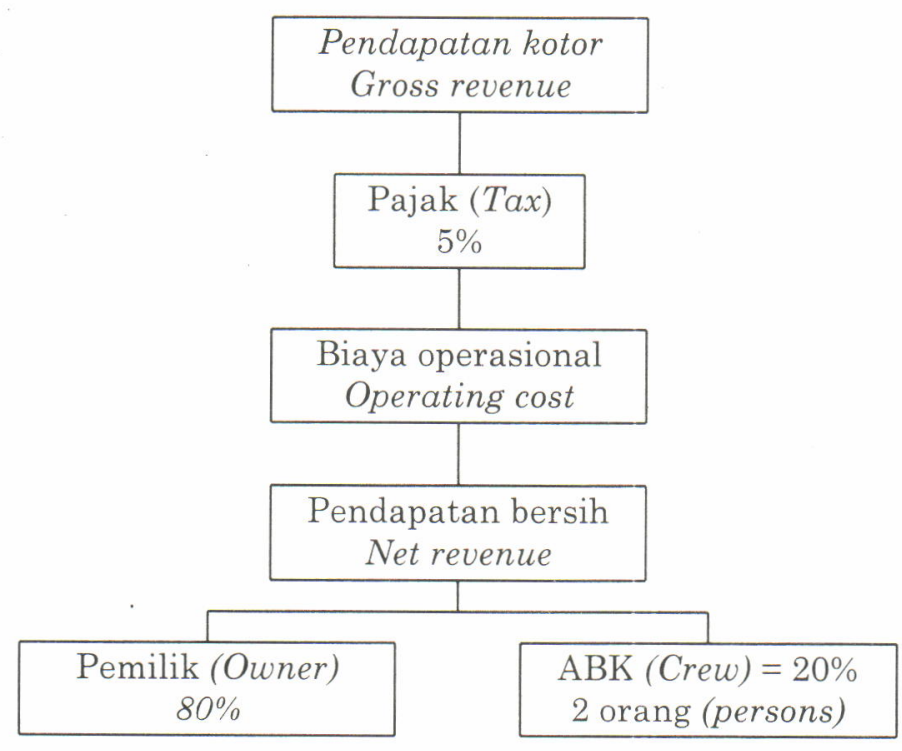

Gambar 3. Sistem bagi hasil ikan yang tertangkap pancing rawai di Batukaras, Ciamis. Figure 3. The sharing system of drift longline fish caught in Batukaras, Ciamis. 
tersebut dengan sistem bagi hasil yang berlaku di Batukaras menunjukkan sistem bagi hasil yang belum memadai.

\section{Rekapitulasi per Tahun Unit Usaha Pancing Rawai}

Tabel 6 menunjukkan biaya yang dikeluarkan untuk pengoperasian alat tangkap pancing rawai sebesar Rp 6.638.800,- per tahun. Biaya-biaya ini berasal dari biaya penyusutan unit alat tangkap Rp 596.800,- per tahun, biaya operasional Rp 5.832 .000 ,- per tahun dan biaya perawatan alat (perahu dan mesin) Rp 210.000,- per tahun.

Pendapatan kotor (raman kotor) sebesar Rp 26.939.000,- dari hasil penjualan hasil tangkapan yang terdiri atas kakap merah $3.546 \mathrm{~kg}$, kerapu $1.596 \mathrm{~kg}$ dan ikan lainnya $10.892 \mathrm{~kg}$. Harga kakap merah per kg Rp 2.500,-; kerapu Rp 4.500,- dan ikan lainnya rata-rata $\mathrm{Rp} 1.000,-$.

Biaya yang dikeluarkan untuk biaya lelang (retribusi) 5\% dari raman kotor $\mathrm{Rp} 1.346 .950$,- per tahun. Pendapatan unit usaha penangkapan pancing rawai sebelum bagi hasil Rp 18.953.250,-. Pendapatan ini barasal dari raman kotor dikurangi biaya retribusi dan biaya operasional.
Pendapatan bersih yang diterima pemilik setelah bagi hasil Rp 15.170.600,- per tahun (Tabel 6).

Mengingat besarnya $\mathrm{R} / \mathrm{C}$ rasio telah mencapai 2,5 yang berarti $>1$, dapat dikatakan bahwa usaha penangkapan dengan mempergunakan pancing rawai dianggap layak untuk dikembangkan. Selain dapat menutupi biaya operasional juga dapat digunakan untuk mencukupi kebutuhan sehari-hari.

\section{KESIMPULAN DAN SARAN}

\section{Kesimpulan}

Dari uraian hasil pengamatan yang telah disajikan, dapat diambil kesimpulan sebagai berikut:

(1) Daerah penangkapan kakap merah dan kerapu yang dimanfaatkan nelayan di perairan Batukaras adalah di dalam Teluk Parigi. Alat tangkap yang digunakan untuk menangkap ikan karang di perairan tersebut adalah pancing rawai dengan jumlah hari operasi (trip) per bulan rata-rata 18 hari.

(2) Komposisi hasil tangkapan pancing rawai terdiri atas $19,84 \%$ kakap merah, $11,25 \%$ kerapu dan 68,91\% ikan lainnya. Ukuran ikan

Tabel 6. Pendapatan bersih tahunan tahunan pemilik pancing rawai di Batukaras, 1992.

Table 6. Annual net income of drift longline owner in Batukaras, 1992.

\begin{tabular}{lc}
\multicolumn{1}{c}{ Items } & $\begin{array}{c}\text { Nilai (Value) } \\
(\mathbf{R p})\end{array}$ \\
\hline 1. Investasi (Investment) & $2,759,000$ \\
2. Jumlah trip/tahun (Total trip/year) & 216 \\
3. Biaya Tetap (Fixed Cost): Depresiasi (Depreciation) & 596,800 \\
4. Biaya Tidak Tetap (Variable Cost): & \\
- biaya operasional (operation cost) & $5,832,000$ \\
- biaya perawatan (maintenance cost) & 210,000 \\
5. Jumlah biaya (Total cost) & \\
(3 + 4) & $6,638,800$ \\
6. Gross Total Revenue: & $26,939,000$ \\
- Kakap merah $($ Red snapper $)=3,546 \mathrm{~kg}=\mathrm{Rp} 15,170.600$ & \\
- Kerapu (Grouper) $=3,546 \mathrm{~kg}=\mathrm{Rp} \quad 7,182,000$ & \\
- Lainnya (Others) $=10,892 \mathrm{~kg}=\mathrm{Rp} 10,892,000$ & $1,346,950$ \\
7. Pajak (Tax) 5\% & $18,953,250$ \\
8. Revenue before sharing system & \\
9. Net revenue after sharing system & $15,170,600$ \\
- pemilik (owner) $(80 \%)$ & $3,782,650$ \\
- ABK (crew) (20\%) & 2.5 \\
10. R/C ratio & \\
\hline
\end{tabular}


karang yang tertangkap, kakap merah maupun kerapu merupakan ukuran ikan konsumsi (0,4-0,8 kg). Cacth Per Unit Effort ikan karang maupun ikan lainnya cenderung naik pada musim Barat (bulan November s/d Februari) maupun musim Timur (bulan April s/d Juni) dan sebaliknya cenderung turun pada musim peralihan.

(3) Pengusahaan alat tangkap pancing rawai dapat memberikan keuntungan untuk pemilik sebesar Rp 15.170.600,- per tahun. Besarnya nilai $\mathrm{R} / \mathrm{C}$ rasio 2,5 menunjukkan bahwa usaha penangkapan dengan menggunakan alat tangkap pancing rawai layak diusahakan karena dapat memberikan hasil yang menguntungkan, selain dapat menutupi biaya operasional juga dapat digunakan untuk mencukupi kebutuhan keluarga sehari-hari.

\section{Saran}

(1) Pengoperasian alat sebaiknya pada waktu musim Barat ataupun musim Timur.

(2) Cukup besarnya biaya pembelian solar dan umpan yang dikeluarkan dalam usaha penangkapan pancing rawai yang mencapai $81,5 \%$ dari total biaya operasional berpengaruh terhadap perolehan pendapatan. Untuk dapat meningkatkan pendapatan diusahakan penggunaan bahan bakar minyak (solar) dan umpan dikurangi karena dalam operasi penangkapan per tripnya bahan bakar dan umpan masih cukup banyak tersisa.

\section{DAFTAR PUSTAKA}

Ahmad, T., Imanto, P.T. dan Muchari.1991. Operasional Pembesaran Ikan Kerapu dalain Keramba Jaring Apung. Balai Penelitian Perikanan Budidaya Pantai. Maros. 59 pp.
Anonim. 1964. Undang-Undang No. 16 Tahun 1964 Tentang Sistem Bagi Hasil Perikanan. Sekretariat Negara, Jakarta.

Basuki, R., Nikijuluw, V.P.H. dan Budihardjo. 1989. Analisis ekonomi dan distribusi pendapatan perikanan skala kecil di Pangandaran. J. Pen. Perikanan Laut, 51: 45-58.

Dwiponggo, A. 1989. Prospek Perikanan Hiasan Bagi Keperluan Domestik dan Ekspor Non Migas.

Gulland, J. A. 1983. Fish Stock Assessment A Manual of Basic Method. John Willey and Sons chichester. $223 \mathrm{pp}$

Hutomo, M., Hadisubroto, I., Wahyono, M.M. dan Prahoro P. 1991. Potensi dan Penyebaran Sumberdaya Ikan Karang dalam Potensi dan Penyebaran Ikan Laut di Indonesia. Editor: Martosubrioto, P., Naamin, N., dan Malik, B.B.A. Direktorat Jenderal Perikanan, Puslitbang Perikanan, Puslitbang Oceanologi LIPI. Jakarta.14 pp.

Kohno, H., Duray, M. and Sunjoto, P. 1990. A Field Guide to Groupers of South East Asia. Pusat Penelitian dan Pengembangan Perikanan. PHP/ KAN/PT. No. 141./1990. Jakarta. 26 pp.

Mulyanto. 1986. Pemanfaatan terumbu karang metoda pendugaan dan pengelolaan di negara-negara ASEAN. INFIS Manual Seri no.18. Direktorat Jenderal Perikanan \& IDRC. 59 pp.

Nikijuluw. V.P.H., Wahyono, M.M., Sasanti. R. 1988. Perikanan ikan hias laut di Pulau Bali. manajemen dan rentabilitas sumberdaya. J. Pen Perikanan Laut, 45: 59-67.

Riyanto, B. 1982. Dasar-Dasar Pembelanjaan Perusahaan. Fakultas Ekonomi UGM. Yogyakarta.

Subani, W. dan Barus, H.R. 1988. Alat penangkapan ikan dan udang laut di Indonesia . J. Pen. Perikanan Laut, 50: 340 pp.

Yunus, S., Herumurti, Y.E. dan Djamal, R. 1991. Analisis Usaha Penangkapan Pancing Rawai di Juana Kabupaten Pati (Jawa Tengah). J. Pen. Perikanan Laut, 64: 65-75.

Thomas-Tarp T. and Kailola, P.J. 1981. Trawled Fishes of Southern Indonesia and North Western Australia. The Australian Development Assistance Bureau. $408 \mathrm{pp}$ 